\title{
Peter C. Doherty: A Legacy of Mentoring
}

\author{
Ralph A. Tripp ${ }^{1}$ and John Stambas ${ }^{2}$
}

Keywords: mentor, legacy, training, opportunity, assistance, contribution

$\mathbf{V}$ ARIOUS PEOPLE CAN ADVISE but few can mentor because an adviser directs but a mentor guides. This statement reflects the shepherding of students and postdoctoral trainees by Peter Doherty. I am a former postdoctoral fellow from Peter's group who trained in the Doherty laboratory from 1993 to 1997 at St. Jude Children's Research Hospital (SJCRH) in Memphis, TN. In those years, I worked on understanding the rules for T cell-mediated control of viruses, in particular, CD8+ cytotoxic T lymphocytes (CTLs) and CD4+ $\mathrm{T}$ cells and assisted in identifying the rubrics of $\mathrm{T}$ cell memory in a mouse model. I worked with other very talented laboratory members on understanding the $\mathrm{T}$ cell response to negative-strand RNA viruses (influenza and Sendai) and a DNA virus (murine $\gamma$-herpesvirus-68) in an effort to better understand acute versus persistent immune memory responses. These studies led to a better understanding of immunity and host features that favored the conventional view that CD8+ T cells functioned mainly as killers and CD4+ T cells as helpers after respiratory virus infection. I recognized that my career path was my responsibility and was looking for a mentor who would offer edifying criticism, bring passion and enthusiasm for the science, and was driven. I found this in Peter who regularly offered advice mixed with dry humor and wit that was always appreciated and thoughtful. This formula helped me grow as an individual, scientist, and opinion leader, and positively influenced my professional development and those of my trainees.

It is clear that one of Peter's greatest accomplishments is his legacy. He was and remains a mentor to many highquality scientists and leaders in the field. Peter has helped others see the potential of their science and what they could become and direct their energies to productive activities. If nothing else, Peter has walked the path one wants to take reaching his professional pinnacle as a 1996 Nobel Laureate and in mentoring and coaching people. He has the ability to listen and suggest just enough so one can discover the actions needed to go forward. He taught sufficiency, not dependency. I recall that Peter was clear in his thinking and constructive with his communication, as well being an outstanding but demanding writer, and always practiced the highest standards of professionalism. For me, Peter was the type of mentor that I felt comfortable talking to as he encouraged professional development and offered a rapport of support. Peter led by example. After joining the laboratory, I was assigned laboratory bench space next to a clean organized space that I was later told was Peter's space, and he would use it periodically to satisfy a curiosity or explore an idea. I thought it odd that a person of his standing would have time to also do research in the laboratory. Indeed, as my tenure in the laboratory grew, Peter found it harder to spend time at the bench, but his action taught me key lessons such as lead by example as it makes people want to follow you, and to bear down and investigate possibilities. Having Peter at the bench lowered the level of apprehension and disarmed anxiety in the laboratory.

Peter has gone full-circle in his career and trained various scientists as he earned his degrees in veterinary science from the University of Queensland, his doctorate from the University of Edinburgh, was appointed as an associate professor at the Wistar Institute in Philadelphia, appointed as a professor at the John Curtin School of Medical Research, and became chairman of the Department of Immunology at St. Jude's Medical Center in Memphis. He is still training and guiding scholars at the Peter Doherty Institute for Infection and Immunity at the University of Melbourne. This is an amazing decades-long contribution that continues to leave a lasting legacy advancing the field of viral immunology. I have met and become friends with several of Peter's trainees over the years and we lament about the "good old days" of T cell limiting dilution assays to quantitatively estimate the precursor frequency of various $\mathrm{T}$ lymphocyte subsets according to their functional properties in vitro. I recall performing dozens and dozens of 96-well CTL assays assessing antigen-specific $\mathrm{T}$ cell killing of labeled target cells. We also discussed some of the great times we had at Keystone meetings where we would all stay discussing the

\footnotetext{
${ }^{1}$ Department of Infectious Disease, College of Veterinary Medicine, University of Georgia, Athens, Georgia.

${ }^{2}$ School of Medicine, Deakin University, Geelong, Australia.
}

(c) Ralph A. Tripp and John Stambas, 2020; Published by Mary Ann Liebert, Inc. This Open Access article is distributed under the terms of the Creative Commons Attribution Noncommercial License (http://creativecommons.org/licenses/by-nc/4.0/) which permits any noncommercial use, distribution, and reproduction in any medium, provided the original author(s) and the source are cited. 
day's meetings, the people we met, or just catching up over local beverages. There were other entertaining times and one in particular that involved a celebration of Peter winning the 1995 Albert Lasker Basic Medical Research Award for "Cells and immune defense." We gathered at Peter's home in Memphis for a dinner party. People were gathered in his living room while a colleague's parents were looking at the award when Peter decided to light the gas fireplace in the room but got distracted. When Peter later lit the fireplace, the room was suddenly filled with the smell of burnt hairto the chagrin of Peter's eyebrows. Peter was no worse for wear but I could not stop laughing.

Like Ralph, I also trained as a postdoctoral research associate in Peter's laboratory at SJCRH in Memphis (20022004, and subsequently in his laboratory at the University of Melbourne (2004-2009). Over the years, I was struck by how much time Peter gave to people and his level of energy for science. Given his successes and the invitations and demands placed on him, Peter could be excused for not finding time to interact with junior colleagues or students. Instead, Peter often went out of his way to ensure people felt they were included and their voices and opinions heard. My appointment to his Memphis laboratory is one such example. My PhD supervisor and I were sitting in the tea room in the Department of Microbiology and Immunology at the University of Melbourne discussing my future as I had just submitted my thesis and was looking for post-doctoral opportunities. Peter was in the tea room getting a coffee and happened to overhear our conversation. He could have ignored the conversation but instead came over and took an interest in my career. By the end of our conversation he suggested I apply for post-doctoral training in his laboratory. This was a very generous and selfless action, one of many I observed under his tutelage and underscores Peter's commitment to supporting and mentoring the next generation of scientists. I am forever indebted to him for giving me an opportunity.

Postdoctoral scientists typically have limited freedom to explore their own ideas. Peter gave me opportunity with guidance but never micromanaged my science. In his words, we were adults and our future was in our own hands. His skillful mentoring allowed him to guide, support, and inspire trainees while at the same time demanding excellence. I still vividly remember my first day and meeting with Peter in his SJCRH office. Armed with a pen and notepad, I sat in his office nervously awaiting instructions on what projects Peter wanted me to undertake. Instead, Peter asked me what I wanted to work on. My mind raced as I tried to come up with a coherent answer. My interest at the time centered on cellular immunity and vaccines, so we planned experiments to examine $\mathrm{CD} 8+\mathrm{T}$ cell immunity in mutated influenza viruses, rescued using reverse genetics (a collaboration between the Doherty and Webster laboratories), to study the impact of these mutations on immunity. Peter typically encouraged trainees to think for themselves and to let the data determine the path forward. This approach precluded preconceived ideas that often clouded what the data showed. My time at SJCRH also involved development of adjuvanted HIV vaccines, a joint collaboration between Peter and members at SJCRH, which emphasizes the breadth of research and training occurring in Peter's program.

A favorite interaction with Peter would involve gathering around a table discussing results. Peter would delight from the possibilities and potential experiments the data suggested. Observing this reaction from someone who had been in science for decades was inspiring. It is important to note that Peter's scientific support and guidance extended well beyond one's time as a trainee. I still picture the satisfaction in his face when I told him I was offered a tenure-track position at a newly opened Medical School at Deakin University in Geelong, Australia. He offered his support and assistance noting that it was his responsibility to ensure his trainees developed their careers by moving onto new challenges - a mark of a great mentor.

Aside from his tremendous contribution to the field of viral immunology, one of Peter's greatest legacies will be the network of trainees he supported and nurtured throughout his career who now span the globe. One example of how his legacy endures is what occurred in late 2003 at a meeting to honor Peter at the Peabody Hotel in Memphis Tennessee. At this meeting, several current and former trainees met, leading to the development of long, fruitful, and collaborative partnerships that endure today, which have resulted in scientific collaboration, funding, student exchange, collaboration agreements between our respective institutions, and establishment of international programs. None of this would have occurred without Peter. He has built careers by getting involved without being asked, answering the questions that are not being asked, giving consistently while receiving occasionally, and going the extra mile.

Address correspondence to: Dr. Ralph A. Tripp Department of Infectious Disease College of Veterinary Medicine University of Georgia 111 Carlton Street Athens, GA 30602

E-mail: ratripp@uga.edu 